\title{
Berømte danskere
}

\section{Hans Otto Jørgensen}

\section{Berømte danskere}

Berømte danskere, til eksempel Flensted Jensen, så ærke-pære dansk, sådan indtog han Amerika, det løfterige, Guds eget land, selvhjulpen og med kommandorøst, bare stank langt væk af gymnastik, og sådan gjorde han indtryk på de vilde, de fjerprydede i deres reservater, med butterfly i nakken, wiing, fjernbetjening i blazerens brystlomme, en bid ledning af et gammelt høreapparat og en lille til formålet velcamoufleret teknomotor muliggjorde dens arrige rotation, wiing, min Herre, han var ikke født i går.

\section{Vikinger}

Anton Andersen, pensioneret førstelærer fra Jelling, kom ved et tilfælde i samtale med de herrer digterparret Peter Orlovsky og Allen Ginsberg i DSBs intercity over Fynsland. De sad i samme kupé. Peter Orlovsky, i sundhedssandaler og bare ben - det var i januar-februar måned - sagde, efter førstelæren vidt og bredt havde berettet for dem om vore højskoletraditioner og forsamlingshuslivet på landet, beautiful, beautiful... Mens Allen Ginsberg derimod, som den kultiverede jøde han er, rødt slips og studset skæg, var mere forbeholden. Andersen flyttede uroligt på sig, rømmede sig, mens Ginsberg gøende, med lipstickporte og anglo univers, replicerede, where the fuck are the vikings. 